\title{
Implementation of social capital for multipurpose cooperative autonomy
}

\section{Implementasi modal sosial untuk otonomi koperasi serbaguna}

\author{
Andik Fadjar Tjahjono ${ }^{1 *}$, Mustain Mashud ${ }^{2}$, \& Falih Suaedi $^{3}$ \\ ${ }^{1}$ Doctoral Program of Social Science, Faculty of Social and Political Sciences, \\ Universitas Airlangga \\ ${ }^{2}$ Department of Sociology, Faculty of Social and Political Sciences, Universitas Airlangga \\ ${ }^{3}$ Department of Public Administration, Faculty of Social and Political Sciences, \\ Universitas Airlangga \\ Address: ${ }^{1,2,3}$ Jalan Dharmawangsa Dalam, Airlangga, Surabaya, East Java Province \\ Indonesia 60286 \\ E-mail: andik.fadjar.tjahjono-2015@fisip.unair.ac.id
}

Article History: Received 10 February 2021; Accepted 14 December 2021; Published Online 08 February 2022

\begin{abstract}
Only a few cooperatives succeed in utilizing social capital, one of them is the Setia Budi Wanita (SBW) Multipurpose Cooperative, East Java. This study aims to elaborate on social capital utilization that develops the autonomy of a multipurpose cooperative. The research method used was qualitative with a phenomenology approach in SBW Multipurpose Cooperative and data were collected through interviews, focused group discussions, and document review. This study has nine informants, including one East Java cooperative figure, four cooperative administrators, two existing members, and two new members. Various data were traced, among others: profiles of SBW figures, various women empowerment programs, the joint responsibility group system, and collaborative partnership between SBW Multipurpose Cooperative and the Department of Cooperatives and SMEs of East Java Province. The results show that SBW Multipurpose Cooperative has various social capital, among others: the characters of Mursia Zaafril Ilyas and Sri Untari Bisowarno, the bond of the seventeen doctors' wives, a community of 360 members, and fourteen administrators of SBW; values and trust in the network of women's cooperatives. This study concludes that social capital elements enable SBW Multipurpose Cooperative to be an autonomous cooperative. SBW Multipurpose Cooperative can utilize the collaboration of individual, community, and network social capital.
\end{abstract}

Keywords: autonomy of cooperative; Setia Budi Wanita; social capital

\begin{abstract}
Abstrak
Hanya sedikit koperasi yang berhasil memanfaatkan modal sosial, salah satunya adalah Koperasi Serbaguna Setia Budi Wanita (SBW) Jawa Timur. Studi ini bertujuan untuk mengelaborasi pemanfaatan modal sosial yang mengembangkan kemandirian koperasi serbaguna. Metode penelitian yang digunakan adalah kualitatif dengan pendekatan fenomenologi di Koperasi Serbaguna SBW dan pengumpulan data dilakukan melalui wawancara, diskusi kelompok terfokus, dan telaah dokumen. Studi ini memiliki sembilan informan, antara lain satu tokoh koperasi Jawa Timur, empat pengurus koperasi, dua anggota lama, dan dua anggota baru. Berbagai data yang ditelusuri antara lain: profil tokoh SBW, berbagai program pemberdayaan perempuan, sistem kelompok tanggung jawab bersama, dan kerjasama kemitraan antara Koperasi Serbaguna SBW dengan Dinas Koperasi dan UKM Provinsi Jawa Timur. Hasil studi menunjukkan bahwa Koperasi Serbaguna SBW memiliki berbagai modal sosial, antara lain: karakter Mursia Zaafril Ilyas dan Sri Untari Bisowarno, ikatan tujuh belas istri dokter, komunitas beranggotakan 360, dan empat belas pengurus SBW; nilai dan kepercayaan dalam jaringan koperasi perempuan. Studi ini menyimpulkan bahwa unsur modal sosial memungkinkan Koperasi Serbaguna SBW menjadi koperasi yang mandiri. Koperasi Serbaguna SBW dapat memanfaatkan kerjasama modal sosial individu, masyarakat, dan jaringan.
\end{abstract}

Kata kunci: otonomi koperasi; Setia Budi Wanita; modal sosial 


\section{Introduction}

As a power of civil society, cooperatives can grow into an economic force for the welfare of society if they have a strong foundation and develop the social capital they have (Edwards 2009, Gelderblom 2018). Cooperatives that grow as autonomous economic power can manage social capital and establish themselves as institutions that rely on the power of networks, guided by agreed norms and values, and high social trust as an encouragement to achieve shared prosperity (Putnam 2001, Putnam 2002). Also, social capital is participation or collaboration between stakeholders to achieve the same goal (Rustinsyah et al. 2021).

This study examines Setia Budi Wanita (SBW) which is categorized as a Multipurpose Cooperative. SBW carries out several business functions, including producer, consumer, and savings and loans. Based on its membership, SBW is classified as a women's cooperative because all members and administrators of the cooperative are women. SBW's struggle to empower women is based on the fact that many women have difficulty gaining access to financial resources, especially those who are poor, single parents, and work independently (Hernanik 2010, Rustinsyah 2015).

The success and experience of the SBW Multipurpose Cooperative are one of the few cooperative success stories of the many failures of the Indonesian government in the program to empower, develop, and make cooperatives autonomous. Many state cooperative assistance programs lead to state corporatism practices that use cooperatives as a means of perpetuating regime power (Nirbito 2003). State corporatism is generally carried out in community organizations whose goal is to lead to the source of mass mobilization. State corporatism considers cooperatives as representatives of interests, so the state needs to control cooperatives to influence their members on the formulation of general policies. Cooperatives' position as state corporatism is very vulnerable to state intervention (Surbakti 1992).

The government seems to have forgotten the proper position of cooperatives in the state's economic structure as an element of civil society that is economically autonomous because they appear voluntarily, independently, rationally and participatory in their function of growing the economy (Giagnocavo 2012). Cooperatives have another characteristic of the strength of civil society as politically autonomous entities. They can advance themselves and limit state and government power. In essence, they are politically autonomous in the face of state power and economically autonomous because they have selfgenerating and self-supporting aspects (Kaswan 2014, Novkovic \& Golja 2015, ICA 2019).

The concept of Indonesian cooperatives, inspired by Mohammad Hatta's thinking, is that cooperatives must have the principle of kinship. The members of the cooperative have a relationship as relatives in a family so it strengthens the sense of solidarity. Cooperative members should have the attitude of selfesteem and the strength of determination to defend the cooperative's interests and goals (Hatta et al. 1983).

Indonesia's involvement in the development of cooperatives to their current achievements is an adherent of the welfare state, as stated in the national constitution, precisely stated in the preamble text and article 33 of the 1945 Constitution. As written in the preamble text, one of the Indonesian's goals is to "advance the general welfare." Meanwhile, Article 33 of the 1945 Constitution serves as the foundation for the Indonesian economy based on the principle of togetherness and kinship. As a country that promotes prosperity, Indonesia has the right to interfere in all areas of the lives of its citizens to ensure the realization of welfare. The state can play a role in protecting and regulating its citizens' economy to avoid social inequality as a result of free trade. The welfare state's conception is closely related to affirmative action, where government policies protect cooperatives. Logically, if the government succeeds in empowering cooperatives, it can confidently empower marginalized groups in society (Haryanto 2016).

Government-cooperative relations are practiced differently by many countries. In some developing countries, the role of government is generally very aggressive in empowering cooperatives, based on 
the assumption that cooperatives can implement development programs (Guinto \& Otahara 1999). The government should play an active role to assist and aim to stimulate cooperative efforts. The government should maintain its role to stay on track and try not to compel and to replace local initiatives and cooperatives' self-help capabilities and should encourage cooperatives' conditions to grow and develop (ILO 2014).

There are three choices of relations between government involvement and the cooperative movement. First, a relationship that prohibits the government from intervening in any form in the cooperative movement. Second, a relationship that limits government intervention to the cooperative movement. Third, a relationship without boundaries for the government to participate in the cooperative movement (Mendoza 1997, Guinto \& Otahara 1999, Deriada 2005). Each government interprets relations with cooperatives by implementing different policies. However, there is a general agreement throughout the cooperatives that in the formulation and making of political law related to cooperatives, the government in each country must consult with the cooperative movements. The government and cooperatives need to establish a regulatory framework that protects cooperatives from abuse of purpose and keeps cooperatives from being taken over by outsiders (private, free market, and big business). The cooperative sector as a civil society organization can carry out trade and business in a fair market and avoid discriminatory economic practices (ICA 2019).

This study explores how the strength of social capital owned by the SBW Multipurpose Cooperative is useful for developing collective empowerment in East Java to become an autonomous cooperative. The discussion in this study used the social capital theories of Pierre Bourdieu, James Samuel Coleman, and Robert David Putnam. Social capital provides the ability to explain social development and economic activity (Vilpoux \& Oliveira 2011), and the common interest for community empowerment (Cusack 1999, Boggs 2001).

The ability of social capital determines the development of cooperatives in every country (Brummer 2018). The initial idea of social capital dates back to the 1980s when Bourdieu (1986) wrote an academic paper entitled The Forms of Capital. The social world can be understood from the ways and structures that shape it, including the various capitals that surround it. Capital is interpreted as material capital in economics and includes intangible capital, including cultural capital and social capital. Even though social capital is not tangible, it exists in form of community social institutions of resources. Social capital is not a natural aspect but has a dynamic characteristic because it can be built, shaped, managed, maintained, and developed by community members. Social capital has a more significant role in improving people's welfare than the role of economic capital (Bourdieu 1986).

In contrast to the social capital theory of James Samuel Coleman, a sociologist with a strong foothold in economic studies proposed rational choice theory (Jackman \& Miller 1998, Schuller et al. 2000, Li et al. 2003). According to Coleman, social capital is determined by its function because it facilitates the actor's freedom of action, has several elements of social structure, and determines the role of actors in the structure (Coleman 1988a). Coleman's theory is an egocentric to socio-centric shift (Mcclenaghan 2000, Adam \& Rončević 2003).

Meanwhile, Robert David Putnam provides a limitation on social capital as a form of the social institution by involving elements of norms, social trust, and networks, which are used for the common interest in carrying out social change (Putnam 1995). While Bourdieu focuses more on social capital's power on the individual factor and Coleman highlights the community factor as the driver of social change, Putnam offers a complete social capital power. Individual capacity as social capital, of course, transmits values to encourage social change. Likewise, the community element as social capital encourages social change but will not be maximally successful if it does not involve networks and mutual trust (Field 2008, Gelderblom 2018, Asquith 2019). 


\section{Research Method}

This study used a qualitative method with a phenomenological approach. This study gained an integrated understanding of the relationship between the various phenomena under study. Phenomenological research has a relationship between phenomena that occur with the context of events (Merriam \& Tisdell 2015) to maintain wholeness between the subject and the data set, as an integration of the whole (Vredenbergt 1981), which requires description, explanation, and exploration (Eisenhardt 1989).

The research subject was SBW Multipurpose Cooperative, proving that it can develop as an autonomous cooperative without being trapped in national corporatism. The basis for selecting informants was the need to obtain complete data on history, types of business, the dynamics of cooperative development, and forms of government cooperation. The informants' selection was carried out by considering their roles, duties, and responsibilities in developing the SBW Multipurpose Cooperative. The diversity of informants is essential to consider to obtain different experiences about the phenomenon being studied (Creswell 2015).

The informants in this study were nine persons, including (1) a cooperative figure of East Java, ISM, (2) a chairperson 1, UNT, (3) a chairperson 2, RIN, (4) a treasurer, SUD, (5) a business coordinator, HEN, (6) an existing member 1, HER, (7) and existing member 2, WAH, (8) a new member 1, RAT, (9) a new member 2, MUR.

Data were collected through Focus Group Discussions (FGD), field observations, and document reviews from 2017 to 2019 in the era of Governor Soekarwo. In qualitative case study research, the selection of data collection techniques should be flexible to obtain rich data (Yin 2018). The FGD was held twice in 2018 and 2020, aiming to confirm and explore findings from document tracking and direct observation. Field observations and direct observations in the form of visits to the SBW Multipurpose Cooperative office took place four times: May 2018, January 2020, October 2020, and November 2020. Searching for documents via the internet, direct visits to the Department of Cooperatives and SMEs of East Java Province and the Ministry of Cooperatives and Small and Medium Enterprises (SMEs) aim to obtain a complete compilation of information about previous studies and regulations on cooperatives.

The data obtained were analyzed using a grounded strategy with the following analysis stages: (1) writing all field findings and documenting them before they are categorized. For case study research, recorded findings are valuable data and should not be discarded (Yin 2018). (2) Presents tables and graphics for quantitative data (data on financial conditions and cooperative health analysis). Qualitative data are described in narrative form and provided with the analysis that is linked to relevant theories (Howitt \& Cramer 2011). (3) The analysis was carried out continuously to develop the theory. This research departed from the theories attached to the subjects studied, including social capital, cooperatives, economic empowerment, and state corporatism. In a grounded strategy, these theories have been attached to and presented with the data and prove that the grounded strategy does not start based on assumptions or merely hypothetic-deductive constructs (Walliman 2011, Achmad \& Ida 2019, Achmad 2020). (4) Concluding are originating from the analysis of the data findings.

\section{Results and Discussion}

Social change in the form of economic empowerment for the poor in Indonesia emphasizes the importance of the role of natural capital and economic capital (Kaskoyo et al. 2017). The state neglects the critical role of social capital, for example, local norms, local traditions and customs, local wisdom, and local institutions. When Indonesia and many other developing countries design community (economic) empowerment as part of the development of realizing people's welfare, it does not have roots in the community's socio-cultural conditions. Such conditions can lead to a lack of benefits, give rise to a dualistic economic condition (rich and low), and further emphasize the existence of economic and social inequality (Hasan \& Azis 2018). 
Many indigenous Indonesian values and norms can be used as social capital, such as the tradition of cooperation, profit sharing systems, joint responsibility, social gathering, and various local wisdom found in various ethnic groups in Indonesia (Kaskoyo et al. 2017, Lee et al. 2017, Rosalin 2017). They can be developed, managed, and institutionalized as souls of the modern economy. Every form of society's (economic) empowerment must pay attention to social capital's potential strength. History has proven the power of social capital as an essential mechanism for achieving equity and economic growth for the people (Putnam 2001).

The following is a presentation of the identification and analysis of the strengths of social capital owned by SBW Multipurpose Cooperative. Initially, this study planned to analyze social capital, leading to Robert David Putnam's theory of social capital, which consists of values, beliefs, and networks. However, during the data collection process, this study revealed that SBW has another social capital in the form of a character's strength, as identified by Pierre Bourdieu's social capital element and the community strength as stated by James Samuel Coleman. For this reason, the analysis of the strength of social capital in this study was carried out based on three levels of analysis of the strength of social capital, including individuals, communities, and networks as shown in Table 1.

Table 1.

The differences of levels of analysis of social capital theories

\begin{tabular}{lll}
\hline $\begin{array}{c}\text { Level of } \\
\text { analysis }\end{array}$ & \multicolumn{1}{c}{ Social capital elements } & \multicolumn{1}{c}{ Theorist (year) } \\
\hline Individuals & - Figure, name, activity & $\begin{array}{l}\text { Pierre Bourdieu } \\
\text { - Circle of friends, association }\end{array}$ \\
& - Internalization, background & \\
- Social membership & James Samuel \\
Communities & - The presence of community & Coleman (1988) \\
& - The important role of community & \\
& - Community mobility & Robert D. \\
Networks & - Affiliation to any social organizations & Putnam (1993) \\
& - Voluntary membership in organizations & \\
& - Participation in decision making & \\
& - Values, focus, and scope of activities & \\
\hline
\end{tabular}

Source: Bourdieu (1986), Coleman (1988b), Putnam (1993)

\section{Pierre Bourdieu's social capital in the SBW Multipurpose Cooperative}

The analysis of individual social capital, according to Bourdieu, can be traced from the background of social status, economic conditions, cultural environment, and differences in the atmosphere of political power that shape individual capacities to build social relationships (Bourdieu 1986). Often, the atmosphere of political power and social status is considered a condition taken for granted so that individual capacities are raised and strengthened. The conditions of such benefits (history, politics, law, and norms) do not escape Bourdieu's observation because the social position and social opportunities can create potential benefits from individual capacities (Bourdieu \& Wacquant 1992, Rudick et al. 2019).

The strength of individual social capital owned by the SBW Multipurpose Cooperative lies in two critical female figures, namely Mursia Zaafril Ilyas and Sri Untari Bisowarno. They lived at different times but had a prominent role and the SBW Multipurpose Cooperative dynamics. Mursia Zaafril Ilyas struggles to initiate, establish, and grow the SBW Multipurpose Cooperative. Meanwhile, Sri Untari Bisowarno strives to raise, develop, and advance the SBW Multipurpose Cooperative. The role of individuals in developing the power of civil society and community organization is one of Pierre Bourdieu's concepts. As he stated, individual social change factors run an agency with larger structural factors such as power, political systems, laws, and policies (Asquith 2019). The relationship factor between structure and agency shows the individual's decisive role (supported by educational qualifications' adequacy) to 
become a significant social capital (Bourdieu 1986). The social capital of these two individuals is an actual and imaginary resource capable of exerting individual and group power to institutionalize "social connectedness" in achieving group gain and progress (Bourdieu \& Wacquant 1992). Therefore, social capital that can link social relationships can be used by someone to encourage social change as progress (Rudick et al. 2019).

In the SBW Multipurpose Cooperative context, the two women figures' qualifications received recognition from the broader community because of their struggles, hard work, and achievements. It also received recognition from qualifiers (structures), such as the state, the central government, the Ministry of Cooperatives and SMEs, the Provincial Government of East Java, and the Department of Cooperatives and SMEs. The skills, qualifications, and reputation of the two individuals are based not only on the level of their education but also on their successes and strengths in the context of the particular area and social field they are developing (Asquith 2019). Bourdieu's conception of individual social capital is shaped by capabilities, the status of the field of struggle, the impact on the cultural sphere, the symbolism inherent in the individual, family background, status in society, economic conditions, and attachment to certain forms of cultural activity (Field 2008).

According to Pierre Bourdieu's concept of individual social capital, Mursia Zaafril Ilyas who comes from a Madurese family is considered to have modern values as she received her education at Taman Siswa, not an Islamic boarding school. Taman Siswa is a public educational institution that aims to develop its students into human beings who have faith and devotion to God Almighty, freedom of mind and spirit, the nobility of intellect, intelligence and life skills, and physical and spiritual health to be able to live as members of society independently and responsibly for realizing the welfare of the homeland, nation, and humanity (Kusumawijaya 2013).

Mursia's social background and educational experience at Taman Siswa made her a pious, independent, critical, and responsible young woman for her life and her nation. She has the individual capacity to communicate and build social relationships during the struggle for independence and build social relationships with the wives of doctors in Malang City to fight in the economic field. Besides, she received an irresistible historical advantage (Bourdieu: social opportunity and social position), that is her interaction with Sutan Sjahrir, who gave socialist thoughts about struggles in the economic field through cooperatives.

Mursia Zaafril Ilyas had a significant role in her struggle to initiate and establish the SBW Multipurpose Cooperative. Her role, according to Bourdieu, is the capacity and qualification of individuals in developing the strength of civil society and organizing society to carry out social change towards progress. Her role in social change for the lower class's welfare is her attempt to act as an agent in the power structure (Soekarno's regime) in response to politics, law, and state policies.

Pierre Bourdieu's social capital analysis explained that Sri Untari Bisowarno who comes from a Javanese family has a modern view because she pursued higher education at the IKIP Malang (now called the State University of Malang). Untari's experience, who is accustomed to organizing since she was a teenager (an OSIS administrator during junior and senior high school), has established her as a woman with a leadership spirit, critical thinking, and organizational management skills. Her studies at IKIP Malang and her involvement in the Indonesian National Student Movement (GMNI) organization honed her capacities and qualifications to fight for the poor.

GMNI has strengthened Untari's struggle as a nationalist who has the ideology of the Marhaenism as the ideology of popular resistance against all forms of colonialism, which resulted in destitution, poverty, and misery. Through GMNI, Untari received an internalization of Sukarno's Marhaenism ideology, based on his thoughts on Socio-Nationalism, Socio-Democracy, and God Almighty. The ideology of Marhaenisme is a unifying word that has become a symbol for all who are destitute (Multizami 2016, Saefulloh et al. 2020). 
Untari started to develop her capacity in the cooperative, starting as a member then increasing her qualifications as a cooperative extension agent. After that, Untari was entrusted with the management of the SBW Multipurpose Cooperative as the chairman, the first cooperative in Indonesia to implement a joint responsibility system (sistem tanggung renteng). To fight for her cooperative side, Untari chose to be involved in the political world through the Indonesian Democratic Party of Struggle (PDIP). The goal of joining a political party to become a council member is not to make cooperatives a political vehicle. Instead, politics is the vehicle for Untari to improve cooperatives. As a public figure, Untari is known as a politician who is consistent with overseeing and maintaining state political policies to continue to side with cooperatives. She gained a historical advantage by meeting Isminarti Tarigan (Head of Puskowanjati or East Java Women's Cooperative Center, a secondary women's cooperative with 45 primary women's cooperatives spread throughout East Java), who introduced her to cooperative activism. "This social, economic background, organizational experience, and historical benefits have strengthened Untari's capacity and qualifications to strive for the welfare of the poor through cooperatives." (informant ISM).

\section{James Samuel Coleman's community social capital in the SBW Multipurpose Cooperative}

Coleman's conception of social capital adopts rational action's economic principle, which is used in analyzing social systems. The success of individual entrepreneurs or economic drivers in running their business cannot ignore the social organization's influence in the process (Coleman 1988a). Coleman's theory of social capital is an amalgamation of the mid-line theory between the two theoretical paradigms. The first is the functionalist paradigm of social action, as determined by social structures. The second is a rational theory, which states that an actor's goals are determined by maximizing his/her gain (Coleman 1986). In short, Coleman relates individuals' social action in sociology with the rational notion of economics, which states that individuals act independently for personal gain and are not structurally determined (Coleman 1988a).

Coleman sees social capital as a public good in which individual actions benefit the whole. Social capital is a collective group asset to reduce social inequalities that can lead to social status differences and access to power (Wall et al. 1998, Field 2008). Individual involvement in social interactions and social networks is only limited to getting benefits. If the social organization does not provide benefits, then individuals have rational actions to get out of existing social interactions and social networks, as rational choice theory (Coleman 1990). These individuals' rational actions are regulated in a particular social context, which takes into account not only individual actions but also the development of social organizations (Coleman 1987, Gelderblom 2018). The direct contributions of actors benefit the whole, not just the individual. Therefore social capital is something that is owned by groups, not individuals. The strength of family or community social capital is owned by a combination of individual forces or human capital that can influence and encourage social change (Asquith 2019).

In the context of SBW Multipurpose Cooperative, the strength of social capital is divided into two periods: (1) a period of pioneering and establishment, (2) a period of awakening and autonomy. During the pioneering and establishment period, the strength of SBW Cooperative's social capital lay in seventeen wives of doctors who were members of a social gathering group called Setia Budi Wanita. They brought together ideas, time, energy, economic capital, and care to create a better economic life for the low-income family. Seventeen people are collective assets in a social structure that strive for the poor's economic improvement, raise the family economy, and make women economically independent. The effort of the seventeen doctors' wives is to narrow the gap in social inequality. Poverty and women's powerlessness, in Coleman's perspective, is social capital resulting from unsuccessful development. When this inequality was fought for by these doctors' wives, social interaction was formed to be familylike bonds as a pre-cooperative, then officially became the SBW Cooperative. 


\begin{abstract}
"The element of social capital that binds the seventeen doctors' wives is the trust and value of togetherness to bring about social change in the form of women's empowerment through economic autonomy so that it impacts the family welfare of the cooperative's members. Thus, the end of all struggles through cooperatives is the community's prosperity, even though some community members do not participate as members of the SBW Multipurpose Cooperative." (Informant RIN).
\end{abstract}

During the period of awakening and autonomy, the strength of the SBW Multipurpose Cooperative's social capital lies in 360 members and 14 administrators, who unite their fighting power, willingness to sacrifice, jointly and severally bear the losses of the SBW Multipurpose Cooperative, and have the same commitment to rise from a downturn in business. The result of the joint responsibility carried out by these members and administrators is the awakening, progress, and autonomy of the SBW Multipurpose Cooperative.

\title{
Robert David Putnam's social capital in the SBW Multipurpose Cooperative
}

The application of the distinctive values of the SBW Multipurpose Cooperative is accompanied by high trust among members and members' trust in the cooperative, indicating closeness to the concepts in Robert David Putnam's theory of social capital. In the SBW Multipurpose Cooperative context, the strength of social capital lies in building values, trust, and networks. Values are vision and mission, institutional structure, education and training, and joint responsibility systems. A trust consists of conditions of management, finance, and business development. Networks are the strength of cooperation among women cooperatives in East Java and the efforts in dealing with the Provincial Government of East Java.

The social capital values owned by the SBW Multipurpose Cooperative include, among others, the vision and mission, the organizational structure, the membership recruitment system, and the type of business. The SBW Multipurpose Cooperative has a vision "A place for empowerment in the economic, social, and cultural fields through a system of joint responsibility to elevate the dignity, values, and welfare of members and society with professionalism to create independence, quality, and integrity in women." The social capital values contained in the SBW Multipurpose Cooperative are (1) high loyalty and self-sacrifice and (2) consistency in implementing the joint responsibility system. When the SBW Multipurpose Cooperative was on the verge of collapse due to bankruptcy in 1982, most members voiced demands for the return of their deposits. However, the remaining 360 members did not ask for a refund of the deposit. Instead, they voluntarily took the initiative to share the deposit and raise the SBW Multipurpose Cooperative.

\footnotetext{
"As far as I can remember, 360 loyal and surviving members of the SBW Multipurpose Cooperative contributed their deposits jointly and severally, each amounting to IDR 80,000. At that time, the deposit amount of the SBW Cooperative members averaged IDR 120,000 so each member only has IDR 40,000 left. Alhamdulillah, they all did it voluntarily. In 1982, the price of gold per gram was around IDR 2,000 to compare the value of money. So, it can be considered that being a member of the SBW Multipurpose Cooperative at that time was relatively prosperous." (Informant SUD).
}

After obtaining substitution loan funds from Bank Indonesia, with the Minister of Cooperatives' assistance, Bustanil Arifin, for IDR 625,000,000, the spirit of togetherness and willingness to sacrifice of the members of the SBW Cooperative remains strong. All members jointly took the initiative to donate funds of IDR 1,000 per month to complete the substitution fund loan from BI. Since then, the SBW Multipurpose Cooperative has consistently applied the joint responsibility system as the best value, which is its social capital strength. 


\begin{abstract}
"In the process of admitting members, the SBW Cooperative applies a filtering mechanism through groups. One group generally consists of 20 people (women). After going through a process of selection, supervision, and other procedures, the group can officially carry out its obligations as a member. When a group member needs funds suddenly, that need can be immediately proposed and agreed upon. Likewise, if a member whose installments fail to pay, all members must settle it jointly and severally. Joint responsibility is a form of mutual commitment. Every decision and effort to solve problems must be based on group members' mutual agreement, and all group members share this burden." (Informant HER).
\end{abstract}

The essence of the joint responsibility system is the sharing of pleasure and difficulty. Group members must share the advantages and disadvantages of the SBW Multipurpose Cooperative. Because of this joint responsibility system, each group member commits to working hard together to gain a shared perceived profit from the business being carried out. The joint responsibility system functions as an internal monitoring mechanism. Meanwhile, by definition, the joint responsibility system is: joint responsibility among members in one group for all obligations to the cooperative based on openness and mutual trust. To ensure the joint responsibility system functions properly and is implemented effectively, three elements are required, including: (1) groups, (2) obligations, and (3) regulations.

"The group is a forum for gathering activities to fulfill their rights and obligations as members of the SBW Multipurpose Cooperative. Another function of the group is to be a means of communication between group members and communication between members and the SBW Multipurpose Cooperative. More importantly, groups can be a place for the learning process for all members to take place. All groups must hold regular meetings once a month arranged by each group. If each group can implement the joint responsibility system in truth, surely each member's attitude and behavior will change." (Informant HEN).

Each member can animate and realize the six values in the joint responsibility system, including mutual trust, togetherness, openness, discipline, deliberation, and responsibility (as shown in Figure 1). This system is the fundamental value of the SBW Multipurpose Cooperative to grow and develop to become economically autonomous and politically independent (Bisowarno 2019).

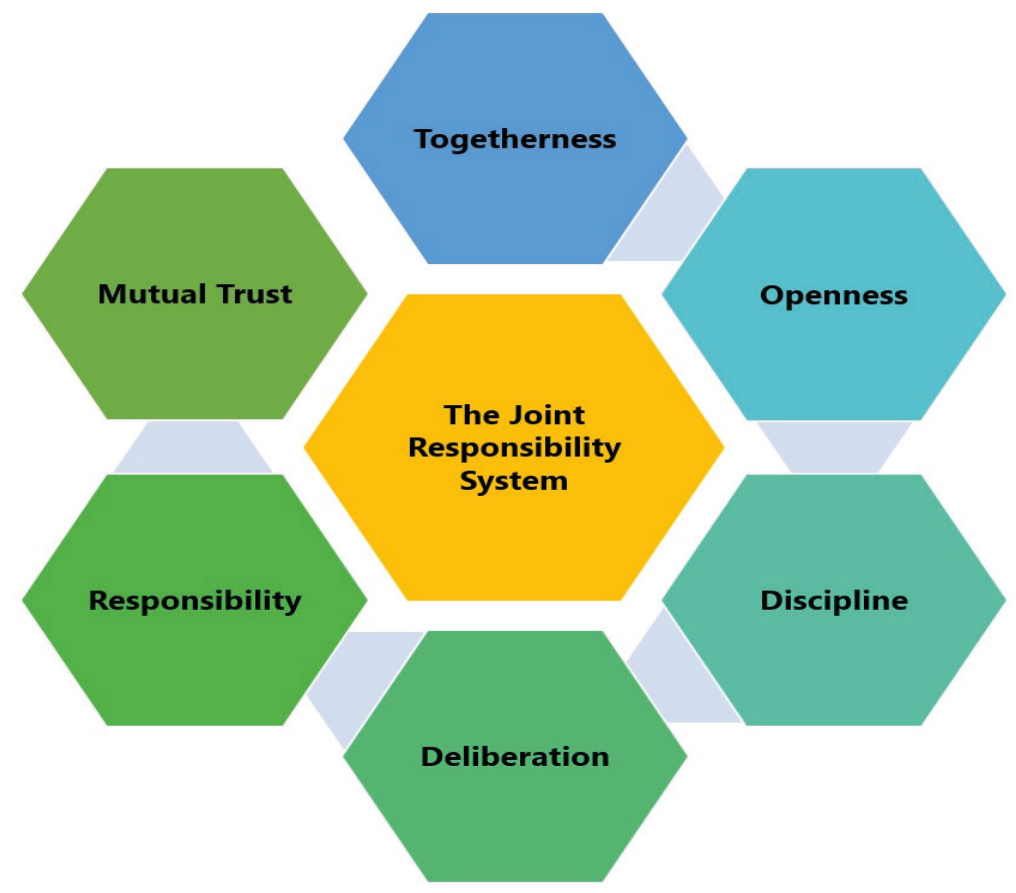

Figure 1.

Illustration of the joint responsibility system with six values of SBW Multipurpose Cooperative Source: Bisowarno (2019) 


\begin{abstract}
"The value of mutual trust manifests in the form of agreement from all group members about the loan plan by the members, and they trust that each member can complete loan repayment obligations. Togetherness is a must for all members to make capital proposals and group business development. Openness means to open opportunities for the community to join as members of the cooperative. Discipline is the compliance of members to a mutual agreement, including a schedule to make installments. Deliberation is a mechanism for solving solutions experienced by group members. Responsibility manifests in the willingness of all group members to make sacrifices for the mistakes made by one of the members." (Informant UNT).
\end{abstract}

The social capital of trust is an internal condition of the SBW Multipurpose Cooperative so that the community voluntarily joins as members and gets the government's trust to develop cooperatives in East Java jointly. The political policy towards cooperatives carried out during Governor Soekarwo's era was carried out through a dialogue process and involved SBW Multipurpose Cooperative. The dialogue resulted in a cooperative empowerment program by adjusting the capacities and capabilities of each cooperative (Dinas Koperasi dan UMKM Provinsi Jawa Timur 2014). Cooperatives with the category of yet-established need to get capital assistance (grants) and various training (Fatmala 2016, Wuryani et al. 2019, Achmad et al. 2020).

The Department of Cooperatives and SMEs of East Java Province has embraced the management of the SBW Multipurpose Cooperative to assist: (1) Managerial development of assisted cooperatives, (2) Improvement of skills and quality of members of assisted cooperatives, (3) Encouragement of cooperative entrepreneurship to realize the interests for prosperity, (4) Improvement of creativity in developing businesses. Those assistance programs are essential because the difficulty that generally occurs after receiving assistance is continuity towards cooperative autonomy (Liani \& Prawihatmi 2017). The development and empowerment of cooperatives in East Java Province by involving partnerships with the SBW Multipurpose Cooperative give hope that more cooperatives will develop to become autonomous.

According to Robert David Putnam, the social network capital is a social organization in the middle of a network of similar organizations and cooperation between these organizations and other similar organizations. The network's existence is closely related to a vast and limited organizational network, like the SBW Multipurpose Cooperative, a partner of the Department of Cooperatives and SMEs of East Java Province. East Java is proving to be a locomotive province for the cooperative movement in Indonesia. In 2013, the allocation of funds for the empowerment of cooperatives and MSMEs disbursed by the East Java Provincial Government amounted to IDR 1.3 trillion. In the same year, eighty employee cooperatives received capital grants, amounting to IDR 25 million to be given to each cooperative. These capital grants gave employees from various companies opportunities to enlarge their businesses and use them as additional funding needs (allocation for health, children's education, or fulfillment of daily living needs). The Provincial Government of East Java has also proven its commitment to supporting cooperative development by distributing assistance for women's cooperatives and Islamic boarding school cooperatives (Budirahayu 2018).

The key to cooperatives' success is facilitating economic justice and economic access to their members without discrimination (Edwards 2009, Gelderblom 2018). The SBW Multipurpose Cooperative has proven its ability to build cooperative networks to contribute to the economic empowerment of women sustainably and have an important role in fighting social exclusion.

The social capital network owned by the SBW Multipurpose Cooperative, with thousands of members and synergizing with Puskowanjati, has a significant impact on creating new jobs, increasing the number of entrepreneurs, and mobilizing the resources owned by its members. That is why the governments in other countries like Greece (Kontogeorgos et al. 2018, Ierapetritis 2019), France (Fares et al. 2018), Taiwan (Liang et al. 2009), and the United States (Grashuis 2018), protect and support cooperative businesses so that they can develop and compete with large companies. 
Based on three theories of social capital proposed by Bourdieu, Coleman, and Putnam, this study identifies any elements of social capital found in SBW Multipurpose Cooperative. First, finding the existence of figures who succeeded in making the SBW Multipurpose Cooperative born and developed. This analysis follows Bourdieu's statement that emphasizes social capital theory analysis at the individual level (Bourdieu 1986, Adam \& Rončević 2003). Second, finding communities that make SBW Multipurpose Cooperative strong in facing the threat of bankruptcy and being free from government capital assistance. This analysis is consistent with Coleman's concept by emphasizing analysis at the community level (Coleman 1988a, Jackman \& Miller 1998, Schuller et al. 2000). Third, find the critical role of the SBW Multipurpose Cooperative with the women's cooperative network in the economic empowerment of women's groups. This analysis follows Putnam's opinion and prioritizes analysis of the strength of social capital at the level of networks, with a comprehensive area scale coverage (Cusack 1999, Lin 2001, Routledge \& Amsberg 2003).

\section{Conclusion}

The social capital owned by the SBW Multipurpose Cooperative includes (1) Individual capital, the qualifications of two female figures who have different roles as founders and developers. (2) Community capital in the form of social ties of seventeen doctor's wives who founded the SBW Multipurpose Cooperative and the 360 members and 14 administrators who saved the SBW Multipurpose Cooperative from bankruptcy. (3) Value capital (vision and mission, management structure, and membership), trust (joint responsibility system and government partnerships), and networks (thousands of members and hundreds of women's cooperatives). The strength of the SBW Multipurpose Cooperative's social capital has functioned itself based on fundamental values: self-help, democracy, self-responsibility, equity, solidarity, and equality.

The social capital owned by the SBW Multipurpose Cooperative can build an ideal relationship with the state in the form of limited collaboration. It means that the government (state) does not allow cooperatives to engage in free competition (liberal) and does not overly intervene in cooperatives (state corporatism). Therefore, the government has made the SBW Multipurpose Cooperative a partner to fight for women empowerment in East Java and has become the most critical partner in forming regional policies for cooperatives in East Java. The government can make the SBW Multipurpose Cooperative empowerment model a strategy replicated in other cooperatives. An autonomous cooperative like the SBW Multipurpose Cooperative can be used as a best practice to transmit good cooperative governance to the management and members of cooperatives developing towards autonomy.

\section{References}

Achmad ZA (2020) Pergeseran relasi antara pendengar radio dengan institusi radio dalam masyarakat jaringan (Studi etnografi virtual pada radio-radio budaya di Jawa Timur yang bermediamorfosis). Dissertation, Universitas Airlangga, Surabaya.

Achmad ZA \& Ida R (2019) The shifting role of the listeners in the mediamorphosis process of culture radio: A case study of Jodhipati 106.1 FM. Masyarakat, Kebudayaan dan Politik 32 (3):240-250. http://dx.doi.org/10.20473/mkp.V32I32019.240-250.

Achmad ZA, Mardliyah S, Siswati E, Luawo SR, \& Wahyudi A(2020) Menumbuhkan upaya diversifikasi usaha melalui penguatan ketrampilan pada komunitas koperasi wanita nelayan di Gresik. Jurnal Abdimas Bela Negara 1 (2):1-14. https://doi.org/10.33005/jabn.v1i2.18.

Adam F \& Rončević B (2003) Social capital: Recent debates and research trends. Social Science Information 42 (2):155-183. https://doi.org/10.1177/0539018403042002001.

Asquith L (2019) Bourdieu and Social Capital. In: Rebuilding Lives After Genocide. Cham: Springer International Publishing, 27-45. http://link.springer.com/10.1007/978-3-030-14074-8_2.

Bisowarno SU (2019) Pemberdayaan perempuan dalam perspektif modal sosial (studi tentang pemberdayaan perempuan melalui kegiatan perkoperasian di Koperasi Setia Budi Wanita Kota Malang). Dissertation, Universitas Brawijaya, Malang. 
Boggs C (2001) Social capital and political fantacy: Robert Putnam's Bowling Alone. Theory and Society 30 (2):281-297. https://doi.org/10.1023/A:1010875611192.

Bourdieu P (1986) The Forms of Capital. In: Richardson J (ed). Handbook of Theory and Research for the Sociology of Education. Westport, CT: Greenwood, 241-258.

Bourdieu P \& Wacquant LJD (1992) An Invitation to Reflexive Sociology. Cambridge: Polity Press.

Brummer V (2018) Of expertise, social capital, and democracy: Assessing the organizational governance and decision-making in German Renewable Energy Cooperatives. Energy Research \& Social Science 37 (October 2017):111-121. https://doi.org/10.1016/j.erss.2017.09.039.

Budirahayu T (2018) Perkembangan koperasi di Jawa Timur. Jurnal Sosiologi Dialektika 13 (1):88-95. http://dx.doi.org/10.20473/jsd.v13i1.2018.88-95.

Burt RS (1998) The gender of social capital. Rationality and Society 10 (1):5-46.

Coleman JS (1986) Social theory, social research, and a theory of action. American Journal of Sociology 91 (6):1309-1335. http://dx.doi.org/10.1086/228423.

Coleman JS (1987) Norms as Social Capital. In: Radnitzky G, Bernholz P (eds). Economic Imperialism: The Economic Approach Applied Outside the Field of Economics. New York: Paragon House. 133-155.

Coleman JS (1988a) Social capital in the creation of human capital. American Journal of Sociology 94:S95-S120. http://dx.doi.org/10.1086/228943.

Coleman JS (1988b) Creation and destrution of social capital: Implications for the law. Notre Dame Journal of Law, Ethics \& Public Policy 3 (3):375-404.

Coleman JS (1990) Foundations of Social Theory. Cambridge and London: The Belknap Press of Harvard University Press.

Creswell JW (2015) Research Design: Qualitative, Quantitative, and Mixed Methods Approaches. 4th ed. Los Angeles: SAGE.

Cusack TR (1999) Social capital, institutional structures, and democratic performance: A comparative study of German local governments. European Journal of Political Research 35 (1):1-34. http:// dx.doi.org/10.1111/1475-6765.00440.

Deriada AL (2005) Assessment of cooperative movement in a developing country: The Philippine experience. Forum of International Development Studies 28 (3):81-101.

Dinas Koperasi dan UMKM Provinsi Jawa Timur (2014) Rencana Strategis Pemberdayaan Koperasi dan Usaha Mikro, Kecil dan Menengah (KUMKM) Provinsi Jawa Timur Tahun 2014-2019. Surabaya: Dinas Koperasi dan UMKM Provinsi Jawa Timur.

Edwards LM (2009) Ideational social capital and the civic culture: Extricating Putnam's legacy from the social capital debates. Social Epistemology 23 (2):125-144. http://dx.doi. org/10.1080/02691720903033457.

Eisenhardt KM (1989) Building theories from case study research. The Academy of Management Review 14 (4):532-550. http://dx.doi.org/10.2307/258557.

Fares M, Raza S, \& Thomas A (2018) Is there complementarity between certified labels and brands? Evidence from small french cooperatives. Review of Industrial Organization 53 (2):367-395. https://doi.org/10.1007/s11151-018-9618-z.

Fatmala A (2016) Signifikansi bantuan permodalan pemerintah pada tingkat rentabilitas koperasi (studi kasus signifikansi bantuan permodalan pemerintah Kabupaten Sidoarjo pada tingkat rentabilitas Koperasi Wanita “Az Zahro"). Kebijakan dan Manajemen Publik 4 (1):1-9.

Field J (2008) Social Capital ( $\left.2^{\text {nd }} e d\right)$. London: Routledge.

Gelderblom D (2018) The limits to bridging social capital: Power, social context and the theory of Robert Putnam. The Sociological Review 66 (6):1309-1324. https://doi.org/10.1177/0038026118765360.

Giagnocavo C (2012) Civil Society, Cooperative Capacity Building and Eradicating Poverty. In: Civil Society Forum Commission for Social Development, The Social Protection Floor Initiative - Bridging the Gap to Poverty Eradication. United Nations, Division for Social Policy and Development, Department of Economic and Social Affairs. 1-10.

Grashuis J (2018) Joint ownership by farmers and investors in the agri-food industry: An exploratory study of the limited cooperative association. Agricultural and Food Economics 6 (24). https://doi. org/10.1186/s40100-018-0118-0. 
Guinto MA \& Otahara T (1999) The role of government in the development of cooperatives in the Philippines. The Review of the Society of Agricultural Economics 55:99-104.

Haryanto R (2016) Peningkatkan ekonomi kerakyatan melalui penguatan managerial koperasi wanita di Kecamatan Pademawu Kabupaten Pamekasan. Nuansa: Jurnal Penelitian Ilmu Sossial dan Keagamaan Islam 13 (2):449-482.

Hasan M \& Azis M (2018) Pembangunan Ekonomi \& Pemberdayaan Masyarakat: Strategi Pembangunan Manusia dalam Perspektif Ekonomi Lokal ( $2^{\text {nd }}$ ed). Makassar: CV Nur Lina dan Pustaka Taman Ilmu.

Hatta M, Widjaja IW, \& Swasono MF (1983) Kumpulan Pidato II (Kumpulan Pidato Mohammad Hatta \#2). Jakarta: Inti Idayu Press.

Hernanik E (2010) Perempuan dan koperasi (studi model pemberdayaan perempuan melalui KWSU Setia Budi Wanita Malang). Muwazah 2 (2):309-324.

Howitt D \& Cramer D (2011) Grounded Theory. In: Introduction to Research Methods in Psychology. Essex: Pearson Education. 343-357.

Ierapetritis DG (2019) Guilds and cooperative community networks in the Eastern Mediterranean: Evidence from Greece under Ottoman occupation. Journal of the Knowledge Economy 10 (4):1578-1596. https://doi.org/10.1007/s13132-016-0428-y.

ICA (2019) Cooperative identity, values \& principles. Coop Int Co-op Alliance, 11 November. [Accessed 20 December 2020]. https://www.ica.coop/en/cooperatives/cooperative-identity\#cooperativeprinciples.

ILO (2014) Promoting Cooperatives: An Information Guide to ILO Recommendation No. 193. Geneva: International Labour Office.

Jackman RW \& Miller RA (1998) Social capital and politics. Annual Review of Political Science 1:4773. https://doi.org/10.1146/annurev.polisci.1.1.47.

Kaskoyo H, Mohammed AJ, \& Inoue M (2017) Impact of community forest program in protection forest on livelihood outcomes: A case study of Lampung Province, Indonesia. Journal of Sustainable Forestry 36 (3):250-263. https://doi.org/10.1080/10549811.2017.1296774.

Kaswan MJ (2014) Developing democracy: Cooperatives and democratic theory. International Journal of Urban Sustainable Development 6 (2):190-205. https://doi.org/10.1080/19463138.2014.951048.

Kontogeorgos A, Sergaki P, Kosma A, \& Semou V (2018) Organizational models for agricultural cooperatives: Empirical evidence for their performance. Journal of the Knowledge Economy 9 (4):1123-1137. http://dx.doi.org/10.1007/s13132-016-0402-8.

Kusumawijaya RI (2013) Konsep paguron Ki Hadjar Dewantara dalam Taman Siswa 1922-1945. Thesis, Universitas Negeri Yogyakarta, Yogyakarta.

Lee Y, Rianti IP, \& Park MS (2017) Measuring social capital in Indonesian community forest management. Forest Science and Technology 13 (3):133-141.

Li Y, Savage M, \& Pickles A (2003) Social capital and social exclusion in England and Wales (19721999). British Journal of Sociology 54:497-526.

Liang Q, Huang Z, Luc H, \& Wang X (2009) Social capital, member participation, and cooperative performance: Evidence from China's Zhejiang. International Food and Agribusiness Management Association 18 (1):49-78.

Liani HHA \& Prawihatmi CY (2017) Dampak pinjaman dan bantuan modal kerja terhadap kinerja usaha (studi kasus UMKM binaan KADIN Jawa Tengah). Jurnal Riset Ekonomi dan Bisnis 10 (3):189201. http://dx.doi.org/10.26623/jreb.v10i3.789.

Lin N (2001) Building a Network Theory of Social Capital. In: Burt R, editor. Social Capital: Theory and Research. New York: Aldine de Gruyter. 3-30.

Mcclenaghan P (2000) Social capital: Exploring the theoretical foundations of community development education. British Educational Research Journal 26 (5):565-582. http://dx.doi. org/10.1080/713651581.

Mendoza EN (1997) The Government and Cooperative Development. In: Agricultural Cooperation in Developing Countries Chapter 2, 19.

Merriam SB \& Tisdell EJ (2015) Qualitative Research: A Guide to Design and Implementation (4 ${ }^{\text {th }}$ ed). San Francisco: Jossey-Bass. 
Multizami AH (2016) Persepsi Gerakan Mahasiswa Nasional Indonesia (GMNI) cabang Semarang terhadap Marhaenisme sebagai ideologi perjuangan. Thesis, Universitas Diponegoro, Semarang.

Nirbito JG (2003) Arah Baru Kebijakan Pembangunan Koperasi di Indonesia dan Strateginya Lewat Jalur Pendidikan. Malang: Universitas Negeri Malang.

Novkovic S \& Golja T (2015) Cooperatives and civil society: Potential for local cooperative development in Croatia. Journal of Entrepreneurial and Organizational Diversity 4 (1):153-169. http://dx.doi. org/10.5947/jeod.2015.008.

Putnam RD (1993) The prosperous community: Social capital and public life. The American Prospect 4 (13):35-42.

Putnam RD (1995) Bowling Alone: America's declining social capital. Journal Democracy 6 (1):65-78.

Putnam RD (2001) Social capital: Measurement and consequences. Isuma: Canadian Journal of Policy Research 2 (Spring 2001):41-51.

Putnam RD (ed) (2002) Democracies in Flux: The Evolution of Social Capital in Contemporary Society. Oxford: Oxford University Press.

Rosalin CC (2017) Social capital and health: The empirical evidence from Indonesia. Thesis, Universitas Indonesia, Depok.

Routledge BR \& Amsberg J (2003) Social capital and growth. Journal of Monetary Economics 50 (1):167-193. https://doi.org/10.1016/S0304-3932(02)00210-6.

Rudick CK, Valdivia FIQ, Hudachek L, Specker J, \& Goodboy AK (2019) A communication and instruction approach to embodied cultural and social capital at a public, 4-year university. Communication Education 68 (4):438-459. http://dx.doi.org/10.1080/03634523.2019.1642501.

Rustinsyah (2015) Social capital and implementation of subsidized fertilizer programme for small farmers: A case study in rural Java, Indonesia. International Journal of Rural Management 11 (1):25-39. https://doi.org/10.1177/0973005215572730.

Rustinsyah R, Prasetyo RA, \& Adib M (2021) Social capital for flood disaster management: Case study of flooding in a village of Bengawan Solo Riverbank, Tuban, East Java Province. International Journal of Disaster Risk Reduction 52:1-10. https://doi.org/10.1016/j.ijdrr.2020.101963.

Saefulloh F, Komalasari K, \& Bestari P (2020) Pola pendidikan demokrasi Pancasila melalui organisasi kemahasiswaan. JIPIS 29 (1):16-22.

Schuller T, Baron S, \& Field J (2000) Social Capital: A Review and Critique. In: Schuller T (ed). Social Capital: Critical Perspectives. Oxford: Oxford University Press. 1-39.

Surbakti R (1992) Memahami Ilmu Politik. Jakarta: Gramedia Widya Sarana.

Vilpoux OF \& Oliveira MAC (2011) Governanças Na Agricultura Familiar: Mercados, Contratos, Redes E Cooperativismo. Curitiba: CVR. Wenger.

Vredenbergt J (1981) Metode dan Teknik Penelitian Masyarakat. Jakarta: Gramedia.

Wall E, Ferrazzi G, \& Schryer F (1998) Getting the goods on social capital. Rural Sociol 63 (2):300-322. https://doi.org/10.1111/j.1549-0831.1998.tb00676.x.

Walliman N (2011) Research Methods: The Basics. London and New York: Routledge.

Wuryani E, Puspasari D, \& Puspasari D (2019) Pengembangan model akses modal bagi koperasi dan UMKM di Jawa Timur. Cakrwala Jurnal Litbang Kebijakan 13 (1):93-108.

Yin RK (2018) Case Study Research and Applications: Design and Methods (6 $6^{\text {th }}$ ed.). Thousand Oaks, CA: Sage. 